\title{
NUCLEAR LOCALIZATION OF ARABIDOPSIS 'S HEAT SHOCK FACTOR HSFA1D USING BIMOLECULAR FLORESCENCE COMPLEMENTATION (BIFC) SYSTEM
}

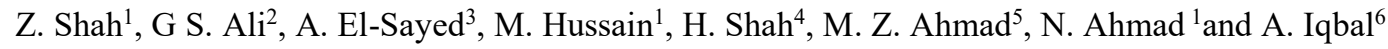 \\ ${ }^{1}$ Department of Biotechnology, University of Science and Technology Bannu, KP, Pakistan; ${ }^{2}$ MREC-University of \\ Florida, 2725 Binion Rd, Apopka, FL, USA 32703; ${ }^{3}$ Botany and Microbiology Department, Faculty of Science, Zagazig \\ University Egypt; ${ }^{4}$ Plant Science Division, Pakistan Agriculture Research Council, Islamabad, Pakistan; ${ }^{5}$ Guangdong \\ Provincial Key Laboratory of Plant Molecular Breeding, College of Agriculture, South China Agriculture University \\ Guangzhou 510642, Gaungdong, China; ${ }^{6}$ Department of Botany, Islamia College Peshawar, KP, Pakistan. \\ arshad.iqbal@icp.edu.pk \\ Corresponding author's email: zamarud_gd@yahoo.com
}

\begin{abstract}
Response to thermal stress in plants is mostly regulated by heat shock factors $(h s f s)$. Among hsfs, HsfAld is one of the key players in protecting plants against heat stress. Subcellular localization of gene is prerequisite for its characterization. Bimolecular Fluorescent Complementation (BiFC) provides the most advance and reliable tool to visualize protein-protein interactions and to explore their location in living system. Objective of the present study was to accomplish sub cellular localization of HsfAld by using BiFC. HsfAld was cloned in-frame with complementary halves of yellow florescent proteins $(Y F P)$ using gateway cloning system. The $\mathrm{BiFC}$ constructs along with positive control were introduced into plant cells through agro-infiltration. The non-florescent fragments of YFP tagged with HsfAld produced no signal when they were infiltrated alone in tobacco leaves. The $\mathrm{N}$ and $\mathrm{C}$ termini of $Y F P$ fused with $H s f A l d$ resulted in florescence upon coexpression in tobacco leaf epidermal cells. The intact YFP tagged with HsfAld, after DAPI staining, was observed under 3 different laser beams of YFP, DAPI and merged. The same florescent signals detected under different channels of laser scanning confocal microscope confirmed the nuclear localization of HsfAld. It is concluded, that HsfAld is localized in the nucleus of cell.
\end{abstract}

Key words: $H s f A 1 d$, subcellular localization, yellow florescent proteins, gateway cloning, BiFC

https://doi.org/10.36899/JAPS.2021.4.0313

Published online December 18, 2020

\section{INTRODUCTION}

Proteins interact during every physiological process to perform their biological function. For example, DNA replication, assembly of translation apparatus, regulation of gene expression at different levels, DNA packaging and signal transduction involve protein-protein interaction (Scott et al. 2016). Thus, the investigation and characterization of various types of proteins interactions occur in the cell are important to understand the various aspect of cytology. Variety of techniques has been designed for the detection and analysis of proteins interactions both in vitro and in vivo (Xing et al. 2016). Every technique has its own pros and cons (Citovsky et al. 2006). For example, co-immunoprecipitation is one of the widely used methods to analyze invitro proteins interactions (Zhu et al. 2017). However, the requirements for specific antibodies against target proteins make it more expensive and laborious process. Moreover, Coimmunoprecipitation is associated with cell lysis which hinders the subcellular localization of the test proteins (Yang et al. 2014). Cross-linking and co-fractionation allows detection of in vivo protein-protein interactions, but the involvement of complex biochemical procedures makes it difficult to apply (Chen et al. 2010). Yeast twohybrid $(\mathrm{Y} 2 \mathrm{H})$ is another assay used to visualize in vivo proteins interactions. The high occurrence of falsepositives results and the non-availability of sub-cellular compartments for specific proteins interaction, add to the several drawbacks of this system (Mehla et al. 2017). Sos and Ras offers a different version of two hybrid system for detection of protein interaction. In this system, the complementary fragments of target protein $(\mathrm{N} \& \mathrm{C})$ are fused to the cytoplasmic proteins of interest. The reconstitutions of such fragments during protein interaction degrade the URA3 reporter protein eventually leading to uracil auxotrophy and resistance to 5fluoroorotic acid. Though, these assays do not need the entry of test proteins to the nucleus, yet drawback lies in allowing the interacting proteins to follow native patterns of subcellular localization (Cruz-Migoni et al. 2019). Bimolecular Fluorescent Complementation (BiFC) offers the most advance and novel approach to detect protein interactions directly within the living cell. Proteins interactions occur in any compartment of aerobic cell can be detected by using BiFC (Miller et al. 2015). In this assay, the desired protein is tagged with complementary fragments of florescent protein and the plant cells are 
transformed with both the constructs using agrobacterium. The association of non-florescent complementary fragments results in the restoration of florescent signals and eventually detected in the living plant cells (Kerppola, 2008). Initially, BiFC was limited to study the interacting transcription factors belong to bZIP and Rel family (Hu et al. 2002). Later on, the use of this assay was extended to detect protein interaction in mammalian (Hynes et al. 2004) bacterial (Tsuchisaka and Theologis, 2004) and plants cells (Stolpe et al. 2005). In plants, several expression vectors have been constructed to detect protein interaction in epidermal cells of tobacco and Arabidopsis (Walter et al. 2004). The BiFC vector, that were initially in use, suffered several drawbacks including inadequate cloning site, the requirement of two selectable markers for developing transgenic plants and non-availability of space for the expression of additional reporter genes (BrachaDrori et al. 2004). To come across such problems, a large number of BiFC vectors with expanded MCS have been designed (Walter et al. 2004). The expanded MCS helps in tagging target proteins to complementary halves of auto florescent proteins. Maximum diversity in cloning machinery is important as precise association and integration of the interacting proteins is essential for reconstitution of florescent YFP. In addition to, such vector design provides an opportunity for the BiFC expression cassettes to use the agrobacterium binary plasmids for co-expression of interacting partners (Lai and Chiang, 2013). Moreover, these vectors help us to incorporate more autofluorescent proteins as reporter genes that may act as internal controls and markers of subcellular compartments. BiFC provides the opportunity to monitor transiently interacting proteins without the aid of any sophisticated equipment. Tobacco (Nicotiana benthamiana) offers a model system to be transformed with generated constructs and visualize protein-proteins interaction. Agrobacterium uses $\mathrm{Ti}$ plasmid (tumor inducing) as vehicle for the transport of target gene into the plant genome. The present study aimed at determining subcellular compartment of HsfAld using gateway compatible BiFC system.

\section{MATERIALS AND METHODS}

Cloning of HsfAld in BiFC Vectors: Arabidopsis's HsfAld was tagged with $\mathrm{N}$ and $\mathrm{C}$ termini of YFP in BiFC vectors using LR reaction (Supp. 1). The LR reaction for cloning HsfAld in frame with $\mathrm{N}$ terminus of $Y F P$ was initiated by mixing $p U C 57 G W$-HsfAld (entry clone) and $p G S A 002-n Y F P^{n}$ (destination vector) in ratio of 4and 1 Fmoles respectively followed by the addition of clonaseII enzyme $(0.5 \mu \mathrm{l})$ and placed for 1 hour at room temperature. Similarly, for cloning HsfAld in frame with $\mathrm{C}$ terminus of $Y F P$, the reactants ( $p U C 57 G W-H s f A 1 d$ and pGSA002$n Y F P^{c}$ ) were added in 3.5:1 Fmoles. The resultant mixture was kept for 1 hour at $25{ }^{\circ} \mathrm{C}$. Heat shock method was used to transform stellar cells with cloning product and applied on spectinomycin $(50 \mathrm{mg} / \mathrm{l})$ containing LB plates. The LB plates were incubated overnight at $37^{\circ} \mathrm{C}$. Plasmids were extracted from transformed bacteria using plasmid extraction kit and subjected to digestion with restriction enzyme NOCI for confirmation. The digested DNA fragments were separated through electrophoresis using agarose gel (1\%).

Preparation of Chemically Competent Agrobacteria (GV3101): Single colony of Agrobacteria was inoculated in $5 \mathrm{ml}$ nutrient broth and subjected to overnight shaking $(200 \mathrm{rpm})$ at $28{ }^{\circ} \mathrm{C}$. One $\mathrm{ml}$ of the resultant culture was mixed with fresh nutrient broth $(50 \mathrm{ml})$ and grown at 28 ${ }^{\circ} \mathrm{C}$ till the $\mathrm{OD}_{600}$ reached to 0.6 . Further bacterial growth was stopped by keeping the culture on ice $(30 \mathrm{~min})$ and distributed in 2 sterile tubes equally. The bacterial culture was subjected to centrifugation $(4000 \mathrm{~g})$ for $5 \mathrm{~min}$. The pellet was re-suspended in $15 \mathrm{ml} \mathrm{CaCl}_{2}(50 \mathrm{mM})$ and placed on ice for $15 \mathrm{~min}$ followed by centrifugation (3800 g) for $5 \mathrm{~min}$. The pellet was re-suspended in $2 \mathrm{ml} \mathrm{CaCl}_{2}$ $(50 \mathrm{mM})$ supplemented with glycerol $(15 \%)$. Aliquots were made and stored at $-80^{\circ} \mathrm{C}$.

Transformation of competent Agrobacteria: Competent agro-bacterial cells $(10 \mu \mathrm{l})$, after thawing, were mixed with plasmid DNA $(1 \mu \mathrm{l})$ and placed on ice for $8 \mathrm{~min}$. The cells were first subjected to cold treatment $\left(-80{ }^{\circ} \mathrm{C}\right.$ for $\left.5 \mathrm{~min}\right)$ followed by incubation for $5 \mathrm{~min}$ at $37^{\circ} \mathrm{C}$ and kept on ice for $1 \mathrm{~min}$. Fresh nutrient broth $(1 \mathrm{ml})$ was added to the cells and grown at $28^{\circ} \mathrm{C}$ under $200 \mathrm{rpm}$. The cells were centrifuged $(8,000 \mathrm{~g})$ for $1 \mathrm{~min}$ and the pellet was resuspended in nutrient broth $(50 \mu \mathrm{l})$. Cells were applied to nutrient agar plates with spectinomycin $(50 \mathrm{mg} / \mathrm{l})$ and placed for 2 days at $28^{\circ} \mathrm{C}$. In this way, agrobacteria were transformed with cloned BiFC vectors along with pGWB442-YFP-HsfAld (positive control).

\section{Transient Transformation of Tobacco Leaves}

Inoculums preparation: Single colony of transformed Agrobacteria was added to nutrient broth $(5 \mathrm{ml})$ with spectinomycin $(50 \mathrm{mg} / \mathrm{l})$ and subjected to overnight shaking $(200 \mathrm{rpm})$ at $28{ }^{\circ} \mathrm{C}$. The resultant culture was centrifuged $(3000 \mathrm{~g})$ for $5 \mathrm{~min}$ and the pellet was resuspended in autoclaved water $(20 \mathrm{ml})$ followed by recentrifugation, using same rpm and time. The pellet was re-suspended in MMA solution (5 $\mathrm{ml}$ ) and kept for 2 hours at $25^{\circ} \mathrm{C}$. Final volume of inoculums was adjusted to $10 \mathrm{ml}$ with $\mathrm{OD}_{600}$ of 0.6 using MMA solution. Equal volumes (5 $\mathrm{ml}$ ) of agro inoculums harboring pGSA002-NYFPHsfA1d and pGSA002-CYFP-HsfA1d were mixed.

Infiltration of tobacco leaves: For $\mathrm{BiFC}$, two weeks old tobacco seedlings (Sup. 1) were divided into 4 groups. Each group of seedlings was infiltrated with $5 \mathrm{ml}$ of different constructs i.e $p G W B 442-Y F P$-HsfAld (positive control), pGSA002-NYFP-HsfAld (negative control), 
pGSA002-CYFP-HsfAld (negative control) and mixture of pGSA002-NYFP-HsfAld + pGSA002-CYFP-HsfAld (test). The infiltrated seedlings were exposed to dark for 40 hours and observed for florescence. The florescent leaf segments (test samples) were stained with DAPI (4',6diamidino-2-phenylindole) reagent for $20 \mathrm{~min}$ and reobserved under 3 different channels ((YFP, DAPI and merged), using confocal microscopy.

Confocal microscopy: One cm of infiltrated leaf segment was placed on microscopic slide with upside down and about $30 \mu \mathrm{l}$ H2O was added. The leaf piece was covered with cover glass and fixed using adhesive tape on both sides. Olympus laser scanning confocal microscope was used for images.

\section{RESULTS}

Heat shock factor (HsfAld) was tagged with complementary halves of YFP using gateway cloning system (LR reaction; Fig 1A \& B).

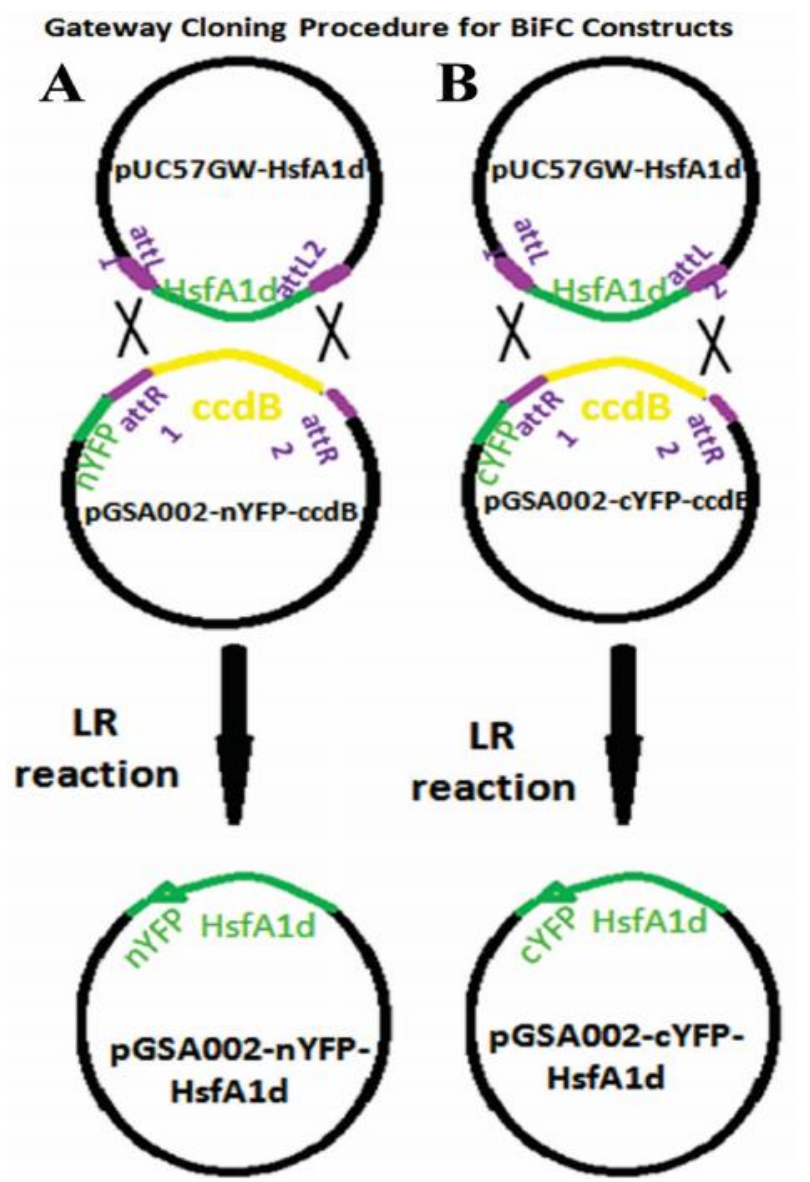

Figure1. Gateway procedure (LR reaction) for cloning HsfAld in frame with, (A) $\mathrm{N}$ terminus of $\mathrm{YFP}$ and (B) $C$ terminus of $Y F P$.

E. coli competent cells were transformed with product of the both LR reactions (Supp.2). Three fragments $(10702,1121$ and $391 \mathrm{bp})$ were observed upon digestion of $p G S A 002-n Y F P-H s f A 1 d$ with restriction enzyme NcoI while the empty vector ( $p G S A 002-n Y F P)$, used as control, resulted in 2 fragments (10557 and 1840 $\mathrm{bp})$. Similarly, restriction digestion-based confirmation of pGSA002-cYFP-HsfAld with NcoI produced 3 fragments (10702, 797 and $391 \mathrm{bp)}$ while 2 fragments (10557 and $1516 \mathrm{bp})$ were observed when the control vector ( $p G S A 002-c Y F P$ ) was subjected to NOCI as shown in the Supp.3. The BiFC vectors where HsfAld has been cloned in frame with $\mathrm{N} \& \mathrm{C}$ termini of $Y F P$ shown in the Figure $2 \mathrm{~A} \& \mathrm{~B}$.

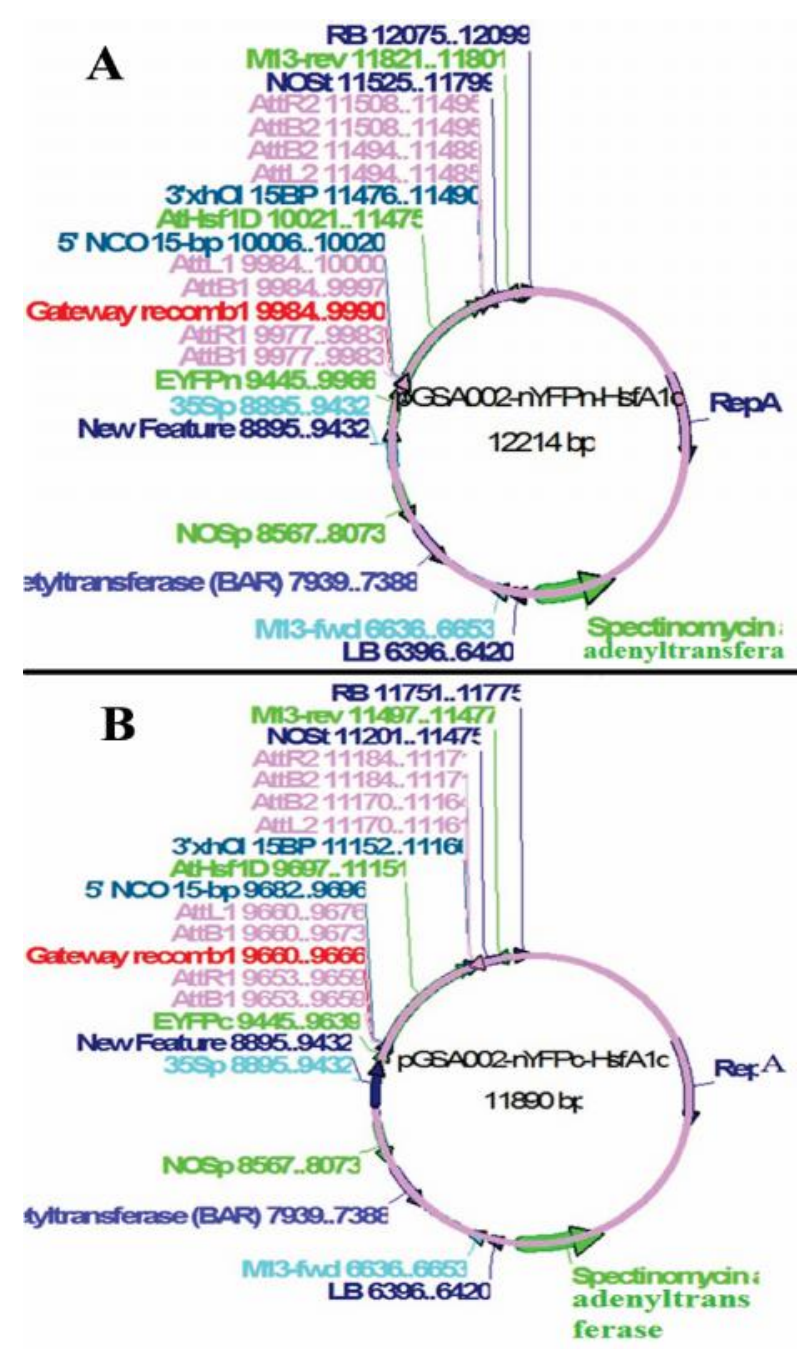

Figure 2. Cloned BiFC vectors, (A) pGSA002-nYFPnHsfAld and (B) pGSA002-nYFPc_HsfAld.

CaMV35S = Promoter, Spectinomycin adenyletransferase $=$ bacteria marker, $\mathrm{NOS}=$

terminator sequence, $E Y F P n=\mathrm{N}$ terminus of $Y F P, E Y F P c=\mathrm{C}$ terminus of $Y F P, H s f A 1 d=$ gene of interest

Competent Agrobacterial cells were successfully transformed with $p G S A 002-n Y F P-H s f A 1 d$ and $p G S A 002-$ 
cYFP-HsfAld (Supp. 4). Tobacco leaves infiltrated $p G W B 442-Y F P-H s f A 1 d$, used as positive control, shown florescence under confocal microscope (Fig. 3A) while no florescence was recorded when $p$ GSA002-nYFP-HsfAld and $p G S A 002-c Y F P-H s f A 1 d$ were expressed alone in tobacco leaf samples (Fig. 3B \& C). Similarly, florescence was observed when pGSA002-nYFP-HsfAld and $p G S A 002-c Y F P-H s f A 1 d$ were co-expressed in tobacco leaves (Fig 3D).

The tobacco epidermal cells, detected positive for florescence, revealed florescence under observing 3 laser beams (YFP, DAPI and merged) using confocal microscopy (Fig. 4).
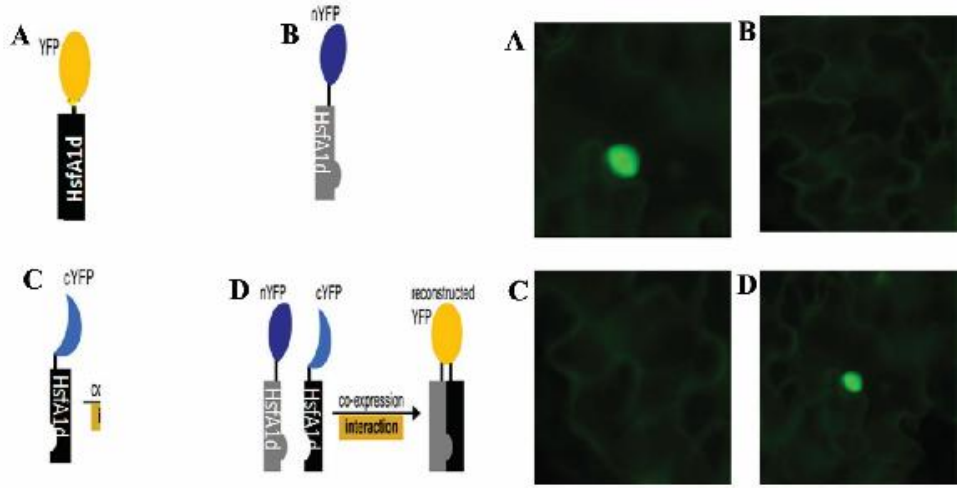

Figure 3. BiFC based detection of $\mathrm{HsfAld}$ in $\mathbf{N}$. benthamiana leaf epidermal cells, (A) YFP tagged with $\boldsymbol{H s f A 1 d}$ (positive control), (B) HsfAld tagged with N terminus of $Y F P$ (negative control), (C) HsfAld tagged with C terminus of YFP (negative control) and (D) Co-expression of $\mathrm{N}$ and $\mathrm{C}$ termini of YFP tagged with $\mathrm{Hs}$ A Ald (test) Scale bar $=10 \mu \mathrm{m}$.

(A) YFP

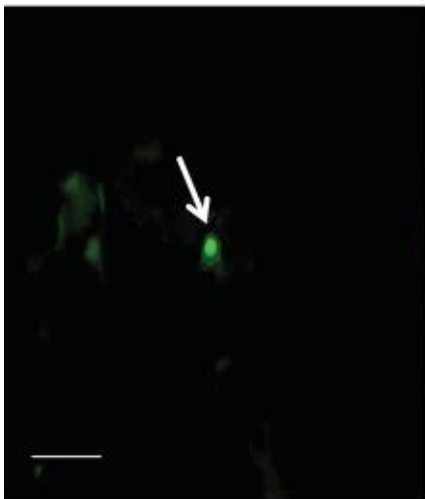

(B) DAPI

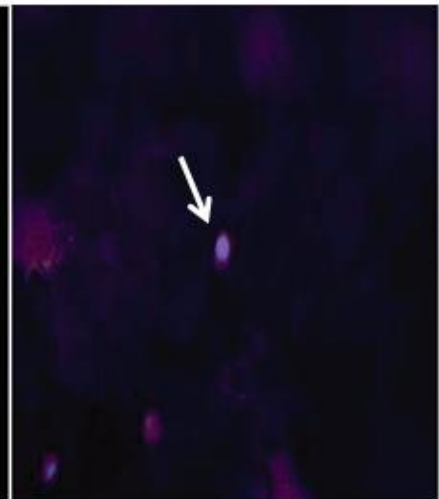

(C) Merged

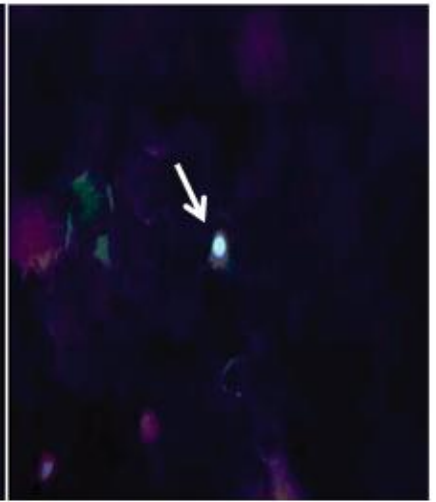

Figure 4. Nuclear localization of $\mathrm{HsfAld}$ in $\mathbf{N}$. benthamiana leaf epidermal cell, Detection of interacting $\mathrm{N}$ and $\mathrm{C}$ termini of YFP tagged with HsfAld under, (A) YFP channel, (B) DAPI channel and (C) Merged channel

\section{DISCUSSION}

The integration of Gateway cloning system and BiFC provide powerful tool to the researchers for understanding protein interactions in the cells. Gateway cloning technique allows the genetic engineers to rapidly design a variety of vectors with high degree of precision (Karna et al. 2018) while the BiFC helps in detection of protein-protein interaction and their subcellular localization (Gookin and Assmann, 2014). The attachment (att) sites lies on the vectors provide a platform for recombination that ultimately leads to gene shuffling (Reece-Hoyes and Walhout, 2018). In the current study, recombination at the attachment sites present on entry clone (aaL1, attL2) and destination vector (attR1, attR2) helped in cloning target gene through LR reaction. The BiFC vectors ( $p G S A 002-n Y F P-H s f A 1 d$ and $p G S A 002-$ cYFP-HsfAld) constructed in the present study strengthened the earlier reports of Karimi et al. (2007), that gateway accurately clone gene cassettes into multiple vectors. Agrobacterium mediated infiltration was successfully used for introduction of BiFC vectors into the tobacco plant. These results are in line with the reports of $\mathrm{Li}$ et al. (2005). The mentioned results are also in agreement with Leckie and Stewart (2011) that agrobacteria extend valuable source for the transport of 
target gene into host plant. Epidermal cells of 4 weeks old Nicotiana benthamiana were transformed with HsfAld tagged with YFP. Similar results exhibited by Schweiger and Schwenkert (2014), further endorsed the utility of Nicotiana benthamiana as model system for transient expression of the target gene. The young age of explants, inoculums OD (0.6) and post infiltration period (42 hours) contributed in successful delivery of $H s f A l d$ fused with auto-florescent protein into tobacco (Bernaudat et al. 2011). Among advanced techniques, BiFC represents one of the most powerful tools for detection and studying protein interactions in living cell (Citovsky et al. 2006). The foundation of this assay lies on reconstitution of fluorescent complex of two complementary fragments of YFP fused to the interacting molecules (Schütze et al. 2009). In the current study, the co-expression of cloned BiFC vectors ( $p G S A 002-H s f A 1 d-n Y F P$ and $p G S A 002-$ $H s f A 1 d-c Y F P$ ) in tobacco cells, extended opportunity for non-florescent $\mathrm{C}$ and $\mathrm{N}$ termini to reconstitute YFP and hence signals were detected. Similar results were also shown by Horstman et al. 2014. No florescence was observed when these vectors were expressed alone, as negative control, in the host cells. These results are in agreement with the reports of Peter et al., (2017). Signals were detected when $p G W B 442-H f_{S A} A 1 d$ tagged with intact YFP was expressed in epidermal cells as positive control. The leaf segments already detected positive for YFP were stained with DAPI and examined under 3 distinct laser beams (DAPI, YFP, merged) for florescence. As DAPI only binds to the nuclear DNA, therefore appearance of florescent proteins tagged with target gene, on the same location under 3 different laser beams accomplished that HsfAld lies in nuclear compartment of the cell. Hernández-Sánchez et al. (2015), ended up with same results upon exposing the host tissues to nuclear dye (DAPI) for subcellular localization of the target gene.

Acknowledgments: The Research facilities were provided by MREC University of Florida USA while financial support was extended by Higher Education Commission Pakistan and University of Science and Technology, Bannu, Pakistan.

Author's contribution: Zamarud Shah conducted the main experiment and collected data. Gul Shad Ali supervised the research. Arshad Iqbal and Hussain Shah helped in manuscript writing. Muhammad Zulfiqar Ahmed and Masroor Hussain contributed in figure setting and data analysis. Ashrf El-Sayed and Nisar Ahmad helped in making the revised manuscript.

Conflict of interest: The authors declare that they have no conflict of interest

\section{REFERENCES}

Bernaudat, F., A. Frelent-Barrand, N. Pochon, S Dementin, P. Hivin, S. Boutigny, J. Rioux, D. Salvi, D. Seigneurin-Berni, P. Richaud, J. Joyard, D. Pignol, M. Sabaty, T. Desnos, E. PebyPeyroula, E. Darrouzet, T. Vernet and N. Rolland. (2011). Heterologous expression of membrane proteins: choosing the appropriate host. PLOS ONE. 6: 12-20.

Bracha-Drori, K., K. Shichrur, A. Katz, M. Oliva, R. Angelovici, S. Yalovsky and N. Ohad (2004). Detection of protein-protein interactions in plants using bimolecular fluorescence complementation. J. Plant. 40: 419-427.

Chen, Z. A., A. Jawhari, L. Fischer, C. Buchen, S. Tahir, T. Kamenski, M. Rasmussen, L. Lariviere, J.Bukowski Wills, M. Nilges, P. Cramer and J. Rappsilber (2010). Architecture of the RNA polymerase II-TFIIF complex revealed by crosslinking and mass spectrometry. EMBO J. 29: 717-726.

Citovsky,V., L. Lee, S. Vyas, E. Glick, M. Chen, A. Vainstein, Y. Gafni, S.B. Gelvin and T. Tzfira (2006). Subcellular localization of interacting proteins by bimolecular fluorescence complementation in planta. J. M. Biol. 362 (5): 1120-1131.

Cruz-Migoni, A., P. Canning, C. E. Quevedo, C.J.R. Bataille, N. Bery, A. Miller, A.J. Russell, S.E.V. Phillips, S.B. Carr and T.H. Rabbitts (2019). Structure-based development of new RASeffector inhibitors from a combination of active and inactive RAS-binding compounds. PNAS 116 (7): 2545-2550

Gookin, T.E. and S.M. Assmann (2014). Significant reduction of BiFC non-specific assembly facilitates in planta assessment of heterotrimeric G-protein interactors. Plant J. 80: 553-567

Horstman, A., I. Tonaco, K. Boutilier and R. Immink (2014). A cautionary note on the use of splitYFP/BiFC in plant protein-protein interaction studies. Int J Mol Sci. 15: 9628-9643

Hu, C.D., Y. Chinenov and T.K. Kerppola (2002). Visualization of interactions among bZIP and Rel family proteins in living cells using bimolecular fluorescence complementation. Mol. Cell. 9: 789-798.

Hynes, T.R., L. Tang, S.M. Mervine, J.L. Sabo, E.A. Yost, P.N. Devreotes and C.H. Berlot (2004). Visualization of $\mathrm{G}$ protein beta gamma dimers using bimolecular fluorescence complementation demonstrates roles for both beta and gamma in subcellular targeting. J. Biol. Chem. 279: 3027930286

Hernández-Sánchez, I.E., I. Maruri, A. Ferrando, J. Carbonell, S.P. Graether and J.F. Jimenez Bremont (2015). Nuclear localization of the 
dehydrin Opsdhn1 is determined by histidine-rich motif. Front Plant Sci. 6: 702

Karimi, M., A. Depicker, and P. Hilson (2007). Recombinational Cloning with Plant Gateway Vectors. Plant Physiol 145(4): 1144-54.

Karna, S.R., X. Zogaj, J.R. Barker, J. Seshu, S.L. Dove and K.E. Klose (2018). A bacterial two-hybrid system that utilizes Gateway cloning for rapid screening of protein-protein interactions. Biotechniques. 49 (5): $831-833$

Kerppola, T.K. (2008). Bimolecular fluorescence complementation (BiFC) analysis as a probe of protein interactions in living cells. Annu Rev Biophys. 37: 465-87.

Leckie, B.M. and C.N. Stewart (2011). Agroinfiltration as a technique for rapid assays for evaluating Candidate insect resistance transgenes in plants. Plant Cell Rep. 30: 325-334

Lai, H., and C. Chiang (2013). Bimolecular Fluorescence Complementation (BiFC) Assay for Direct Visualization of Protein-Protein Interaction in viv. Bio Protoc. 3(20): e935.

Li, J., A. Krichevsky, M. Vaidya, T. Tzfira and V. Citovsky (2005). Uncoupling of the functions of the Arabidopsis VIP1 protein in transient and stable plant genetic transformation by Agrobacterium. Proc. Natl Acad. Sci. USA 102: 5733-5738.

Mehla, J., J.H.Caufield, N.Sakhawalkar, and P.Uetz (2017). Chapter Seventeen - A Comparison of Two-Hybrid Approaches for Detecting ProteinProtein Interactions. Method Enzymol. 586: 333358.

Miller, K. E., Y. Kim, W. Huh, and H. Park (2015). Bimolecular fluorescence complementation (BiFC) analysis: advances and recent applications for genome-wide interaction studies. J Mol Biol. 427(11): 2039-2055.

Reece-Hoyes, J.S., and A.J.M. Walhout (2018). Gateway Recombinational Cloning. Cold Spring Harb Protoc.

2018(1): pdb. top094912.

Peter, S., S.Z. Oven-Krockhaus, M. Veerabagu, V.M. Rodado, K.W. Berendzen, A.J. Meixner, K. Harter and F.E. Schleifenbaum (2017). Chimeric Autofluorescent Proteins as Photophysical Model System for Multicolor Bimolecular Fluorescence
Complementation. J Phys Chem B. 121(11): 2407-2419.

Schütze, K., K. Harter,and C. Chaban (2009).Bimolecular Fluorescence Complementation (BiFC) to Study Protein-Protein Interactions in Living Plant Cells. Methods Mol Biol. 479: 189-202.

Schweiger, R., and S. Schwenkert (2014). Protein-protein interactions visualized by bimolecular fluorescence complementation in tobacco protoplasts and leaves. J. Vis. Exp. (85): e51327.

Scott, D. E., A.R. Bayly, C. Abell and J. Skidmore (2016). Small molecules, big targets: drug discovery faces the protein-protein interaction challenge. Nat. Rev. Drug Discov. 15: 533-550.

Stolpe,T., C. Süsslin, K. Marrocco, P. Nick, T. Kretsch, and S. Kircher (2005). In planta analysis of protein-protein Interactions related to light signaling by bimolecular fluorescence complementation. Protoplasma. 226: 137-146.

Tsuchisaka, A., and A. Theologis (2004). Heterodimeric interactions among the 1-amino-cyclopropane-1carboxylatesynthase polypeptides encoded by the Arabidopsis gene family. Proc. Natl Acad. Sci. USA. 101: 2275-2280.

Walter, M., C. Chaban, K. Schütze, O. Batistic, K. Weckermann, C. Näke, D. Blazevic, C. Grefen, K. Schumacherand C. Oecking(2004). Visualization of proteininteractions in living plant cells using bimolecular fluorescence complementation. J. Plant. 40: 428-438.

Xing, S., N. Wallmeroth, K.W. Berendzen and C. Grefen (2016). Techniques for the Analysis of ProteinProtein Interactions in Vivo. Plant Physiol. 171(2): 727-758.

Yang, J.W., J.X. Fu, J. Li, X.L. Cheng, F. Li, J. F. Dong, Z.L. Liu, and C.X. Zhuang (2014). A Novel Coimmunoprecipitation Protocol Based on Protoplast Transient Gene Expression for Studying Protein- protein Interactions in Rice. Plant Mol. Biol. Rep 32(1): 153-161

Zhu, X., A. Zelmer, and S. Wellmann (2017). Visualization of Protein-protein Interaction in Nuclear and Cytoplasmic Fractions by Coimmunoprecipitation and In Situ Proximity Ligation Assay. J Vis Exp. (119): 55218. 


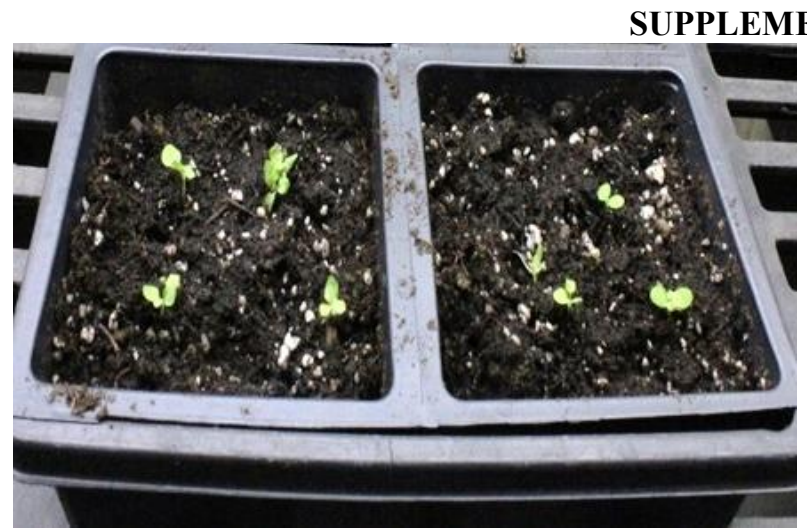

Supp 1. Tobacco leaves used for infiltration of GV3101 harboring BiFC constructs

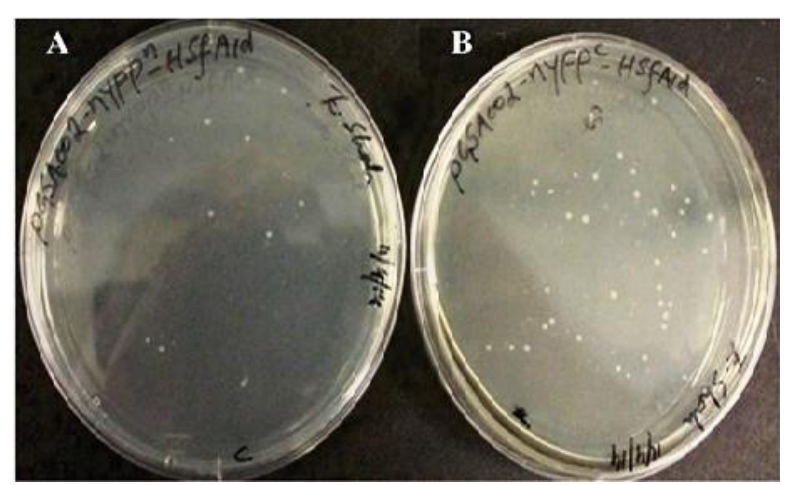

Supp 2. E. coli cells transformed with, (a) pGSA002-nYFP ${ }^{n}$-HsfA1d and (b) pGSA002$n$ YFP $^{c}$-HsfA1d

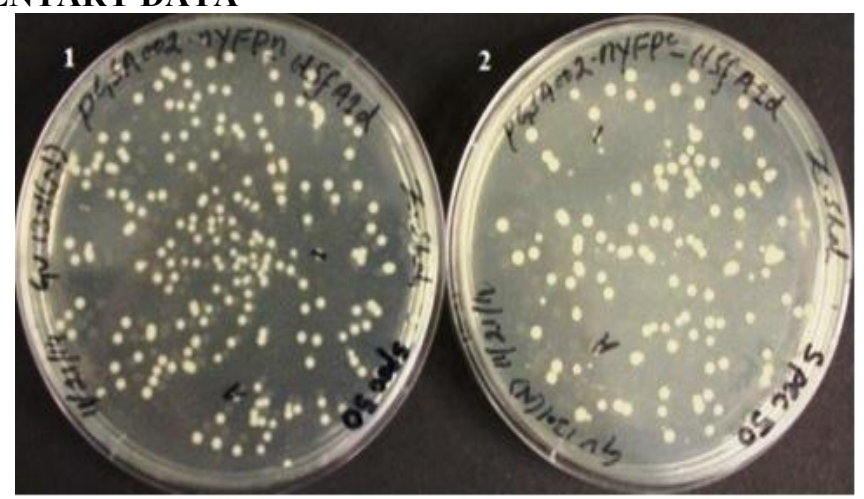

Supp 3. Agrobacterium GV3101 cells transformed with, (a) $p G S A 002-n Y F P{ }^{n}-H s f A 1 d$ and (b) $p G S A 002-$

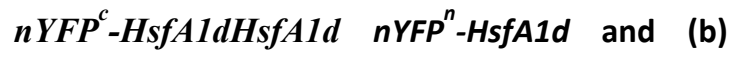
pGSA002-nYFP ${ }^{c}-H s f A 1 d$.

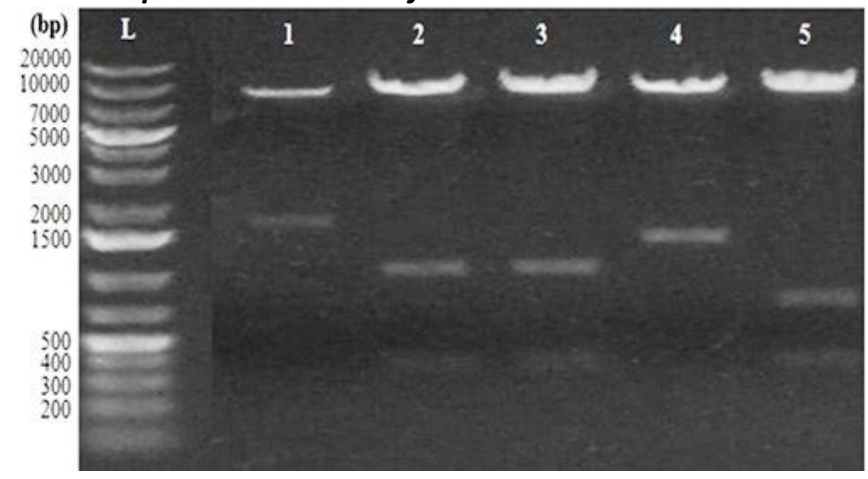

Supp 4. Restriction digestion of cloned BiFC vectors pGSA002-nYFP ${ }^{n}$-HsfAld and pGSA002- $n Y_{F P}{ }^{c}$ HsfAld along with their empty vectors (control) using enzyme $\mathrm{NcoI}$. 